\title{
Accumulation of selected phenolics and expression of PAL genes in carrots differing in their susceptibility to carrot fly (Psila rosae F.)
}

\author{
Magdalena Simlat • Maciej Stobiecki • \\ Marek Szklarczyk
}

Received: 14 May 2012/Accepted: 17 November 2012/Published online: 4 December 2012

(C) The Author(s) 2012. This article is published with open access at Springerlink.com

\begin{abstract}
Three research problems were addressed in this work: an extent of root damage caused by carrot fly (Psila rosae) in a collection of carrot breeding accessions as well as correlation between resistance to this pest and accumulation of certain phenolics and mRNAs of the genes coding for phenylalanine ammonia-lyase (PAL). Differences in susceptibility between the studied accessions were statistically significant. The most resistant were lines 7262A and DC 96367. Moreover, no correlation was observed between accumulation of the specific metabolites and the extent of the root damage. However, proportion of certain phenolics exhibited positive correlation with the resistant phenotype. This was shown for the ratios of luteolin 7-O-glucoside to kaempferol 3-O-glucoside and methyluteolin 7-Oglucoside to kaempferol 3-O-glucoside. Susceptibility of roots to larval damage also correlated with semiquantitatively estimated accumulation of $P A L 1$ and
\end{abstract}

\section{Simlat $(\bowtie)$}

Department of Plant Breeding and Seed Production, University of Agriculture, Łobzowska 24, 31-140

Krakow, Poland

e-mail: m.simlat@ur.krakow.pl

M. Stobiecki

Institute of Bioorganic Chemistry, Polish Academy of

Sciences, Noskowskiego 12/14, 61-704 Poznan, Poland

M. Szklarczyk

Department of Genetics, Plant Breeding and Seed

Production, University of Agriculture, 29 Listopada 54,

31-425 Krakow, Poland
PAL3 mRNAs in leaves. Both PAL genes were expressed at the highest level in line DC 96367 and less strongly in line 7262A. Distinctly lower accumulation of the PAL transcripts was observed for the susceptible varieties: Dolanka and Karotan.

Keywords Carrot - Gene expression - PAL . Psila rosae $\cdot$ Secondary metabolites

\section{Introduction}

Carrot fly (Psila rosae F.) is one of the most serious pests of carrot and other Apiaceae crops. The actual damage is inflicted on roots which as a result of larval feeding exhibit the presence of brown blemishes. Although breeding experiments have shown significant differences between carrot materials in their susceptibility to carrot fly damages till now there are no cultivars which are resistant to this pest (Ellis and Hardman 1981; Ellis et al. 1984, 1993; Michalik and Wiech 2000). Experiments carried out in England (HRI Wellesbourne), Sweden, Netherlands and Poland pointed at cultivars Sytan and Long Chantenay as the ones which exhibited the high level of resistance. However, none of the tested breeding accessions showed a $100 \%$ resistance to carrot fly damage. In those experiments complete resistance was observed only in case of wild carrots e.g. Daucus capillifolius (Gilli.) and D. glochidiatus (Labill.) Fisch., Mey. et Ave-Lall. The tolerant cultivars and wild accessions 
were utilized as a source of resistance genes in carrot breeding programs resulting in the release of semiresistant cultivar Flayaway (registered in 1999, Ellis 1999) and some lines which were more resistant than Sytan. The work carried at HRI Wellesbourne proved that resistance to $P$. rosae was a consequence of both genetic and environmental factors indicating that it would be very difficult to improve resistance solely by selection (Finch 1993). There is some evidence that secondary metabolites, especially phenolics, terpenoids and polyacetylenes, may influence the level of resistance. Therefore, biochemical and molecular investigation of these compounds may bring valuable insight into genetic aspects of their accumulation and help to select plants with increased tolerance to the pest. Chlorogenic acid was identified as the main phenolic constituent of carrot roots. Elevated concentration of this compound was correlated with the increased root susceptibility to larval damage (Cole 1985). The concentration of chlorogenic acid was higher in peel than in phloem of the roots (Olsson and Svensson 1997). Similarly Ellis et al. (1991) pointed at chlorogenic acid as a helpful indicator in selection of resistant carrot materials. Moreover, several plant flavonoid glycosides were also shown to act as either attractants or stimulants for herbivores (Delvas et al. 2011, Honda et al. 2011). It was also pointed that it was rather a proportion of some chemicals than their individual content which played an important role in plantinsect interactions. According to Fenny et al. (1988) chlorogenic acid and luteolin-7-O-(6'-O-malonyl)- $\beta$ D-glucopyranoside from carrot foliage served together as oviposition stimulants for black swallowtail butterfly (Papilio polyxenes F.), while neither of the pure compounds was active. Similarly, trans-methyl-isoeugenol and trans-asarone detected in the surface wax of carrot leaves were found to stimulate oviposition of carrot fly (Städler and Buser 1984). In recent years many genes active in the secondary metabolite pathways have been studied (Reymond et al. 2000). Among them, the three PAL genes from Daucus carotaPAL1, PAL3 and PAL4 - were cloned and sequenced (Takeda et al. 1997, Ozeki et al. 2003, Kimura et al. 2008). PAL-phenylalanine ammonia-lyase (EC 4.3.1.5) catalyzes the first reaction in the biosynthesis of many potentially protective secondary compounds such as flavonoides, lignins and phytoalexins.

The purpose of this study was to check if carrot resistance to carrot fly was associated with accumulation of certain phenolics and expression of genes coding for phenylalanine ammonia-lyase (PAL). Both the phenolic content and transcription of PAL genes were studied in leaves of plants from accessions which in the field experiments showed reliable differences in their susceptibility to carrot fly root damage.

\section{Materials and methods}

\section{Plant material}

Susceptibility of carrot breeding accessions to carrot fly larval damages was studied in the field experiments carried out in 2001, 2002 and 2003. The trials were conducted near Kraków-in Węgrzce and Wieliczka where a high occurrence of the pest had been observed and monitored using yellow sticky traps. Altogether, in the field experiments 29 carrot accessions were tested (Table 1). All of them were included in the Wegrzce trial while in Wieliczka only a subset (ten accessions) of those was evaluated. The biochemical and gene expression analyses were performed for the four accessions grown in both field locations: Dolanka, Karotan, 7262A and DC 96367.

\section{Field experiments}

All studied carrot accessions were grown in a randomized block experiment. In Węgrzce seeds were sown on ridges using the Plotmatic $1 \mathrm{R}$ seeder (Wintersteiger) — for a given accession 160 seeds were used along a distance of $2 \mathrm{~m}$ (the ridges were $65 \mathrm{~cm}$ apart). In Wieliczka for each accession 80 seeds were sown manually in a row $1 \mathrm{~m}$ long-the rows were $30 \mathrm{~cm}$ apart. In Wegrzce and Wieliczka the seeds were sown in the end of April in two and four replications, respectively. The roots were harvested in the end of September or in early October. Upon harvesting each root was inspected in order to determine the number of wounds caused by carrot fly. Based on that each root was assigned into one of the following classes: nineno wounds, seven-one wound, five-two wounds, three-three to five wounds, 1 -more than five wounds. These data were used to calculate the percentage of damaged roots and resistance index for each carrot accession.

The resistance index was calculated using the formula: 
Table 1 Plant material used in the study

\begin{tabular}{|c|c|c|c|c|c|c|}
\hline \multirow[t]{2}{*}{ Accession } & & \multirow[t]{2}{*}{ Origin } & \multicolumn{2}{|c|}{ Field experiments } & \multirow{2}{*}{$\begin{array}{l}\text { Biochemical } \\
\text { analysis }\end{array}$} & \multirow{2}{*}{$\begin{array}{l}\text { Molecular } \\
\text { analysis }\end{array}$} \\
\hline & & & Węgrzce & Wieliczka & & \\
\hline AS 884 & BL & PHRO Krzeszowice, Poland & + & & & \\
\hline 2158 & $\mathrm{BL}$ & PHRO Krzeszowice, Poland & + & & & \\
\hline $52274 \mathrm{Fe}$ & $\mathrm{BL}$ & PHRO Krzeszowice, Poland & + & & & \\
\hline $\mathrm{OZ}$ & BL & PHRO Krzeszowice, Poland & + & & & \\
\hline $1028 \mathrm{~A}$ & $\mathrm{BL}, \mathrm{A}, \mathrm{ba}$ & PHRO Krzeszowice, Poland & + & & & \\
\hline 1028B & $\mathrm{BL}, \mathrm{B}$ & PHRO Krzeszowice, Poland & + & & & \\
\hline $2163 \mathrm{~A}$ & $\mathrm{BL}, \mathrm{A}$, pet & PHRO Krzeszowice, Poland & + & & & \\
\hline 2163B & $\mathrm{BL}, \mathrm{B}$ & PHRO Krzeszowice, Poland & + & + & & \\
\hline $10138 \mathrm{~A}$ & $\mathrm{BL}, \mathrm{A}, \mathrm{ba}$ & PHRO Krzeszowice, Poland & + & & & \\
\hline 10138B & $\mathrm{BL}, \mathrm{B}$ & PHRO Krzeszowice, Poland & + & & & \\
\hline $9370 \mathrm{~A}$ & $\mathrm{BL}, \mathrm{A}, \mathrm{ba}$ & PHRO Krzeszowice, Poland & + & & & \\
\hline 9370B & $\mathrm{BL}, \mathrm{B}$ & PHRO Krzeszowice, Poland & + & & & \\
\hline $2874 \mathrm{~A}$ & $\mathrm{BL}, \mathrm{A}$, pet & PHRO Krzeszowice, Poland & + & & & \\
\hline 2874B & $\mathrm{BL}, \mathrm{B}$ & PHRO Krzeszowice, Poland & + & & & \\
\hline $1028 \mathrm{~A} \times 9370 \mathrm{~B}$ & $\mathrm{~F}_{1}$ & PHRO Krzeszowice, Poland & + & & & \\
\hline $2163 \mathrm{~A} \times \mathrm{NAS}$ & $\mathrm{F}_{1}$ & PHRO Krzeszowice, Poland & + & & & \\
\hline $10138 \mathrm{~A} \times 52257 \mathrm{Fe}$ & $\mathrm{F}_{1}$ & PHRO Krzeszowice, Poland & + & & & \\
\hline $9370 \mathrm{~A} \times 2158 \mathrm{C}$ & $\mathrm{F}_{1}$ & PHRO Krzeszowice, Poland & + & & & \\
\hline $2874 \mathrm{~A} \times \mathrm{R} 92$ & $\mathrm{~F}_{1}$ & PHRO Krzeszowice, Poland & + & & & \\
\hline $2163 \mathrm{~A} \times 2158 \mathrm{C}$ & $\mathrm{F}_{1}$ & PHRO Krzeszowice, Poland & + & & & \\
\hline DC 79002 & $\mathrm{BL}$ & HRI Wellesbourne, UK, derived from Danvers & + & + & & \\
\hline DC 84022 & BL & HRI Wellesbourne, UK, derived from Sytan & + & + & & \\
\hline DC 96280 & BL & HRI Wellesbourne, UK, derived from Danvers & + & + & & \\
\hline DC 96367 & $\mathrm{~F}_{4}$ & HRI Wellesbourne, UK, Sytan $\times D$. glochidiatus & + & + & + & + \\
\hline Satrija & $\mathrm{P}$ & ISDI Babtai, Lithuania & + & + & & \\
\hline Dolanka & $\mathrm{P}$ & Polan Snowidza, Poland & + & + & + & + \\
\hline Karotan & $\mathrm{P}$ & Rijk Zwaan, The Netherlands & + & + & + & + \\
\hline $7262 \mathrm{~A}$ & BL, A, pet & USDA ARS & + & + & + & + \\
\hline $7262 B$ & $\mathrm{BL}, \mathrm{B}$ & USDA ARS & + & + & & \\
\hline
\end{tabular}

$\overline{B L}$ breeding line, $P$ open-pollinated variety, $A$ male-sterile maternal line, $B$ male-fertile maintainer line, $b a$ brown anther type, pet petaloid type

Resistance index $=\frac{\sum\left(i \times n_{i}\right)}{9 \times N} \times 100$

where: $i$-class number $(9,7,5,3$ and 1$)-\mathrm{n}_{i}-$ number of roots in the $i$-class, $N$-total number of inspected roots.

Differences in the percentage of damaged roots and resistance index were analyzed using two-factorial analysis of variance for each experimental location (with years and genotypes as factors) and threefactorial analysis for both locations (with years, locations and genotypes as factors). In these analyses the least significant difference (LSD) was calculated using the $t$ student test.

\section{Chemical analysis}

The plant material was collected in July and September of 2003 from the field experiments located in Węgrzce and Wieliczka (see above). Each time, both young and mature (old) leaves were picked-the former from the center and the latter from the periphery of leaf rosettes, respectively. Each $2 \mathrm{~g}$ 
sample was collected in duplicate and contained the leaf material from 21 plants. The samples were frozen in liquid nitrogen and kept in $-80{ }^{\circ} \mathrm{C}$ until extraction. Using mortar and pestle the leaves were powdered in liquid nitrogen and then extracted at room temperature with $80 \%$ methanol $(20 \mathrm{ml} / 1 \mathrm{~g}$ of fresh weight $)$ for $20 \mathrm{~min}$ in an ultrasonic bath (Sonic 5, Polsonic). The resulted suspensions were filtered through a Büchner funnel and concentrated under vacuum to approximately $5 \mathrm{ml}$. Then the samples were solid phaseextracted (SPE) using cartridges filled with RP C-18 silica gel (Sigma-Aldrich). The cartridges were activated with $5 \mathrm{ml}$ of $96 \%$ methanol and then $5 \mathrm{ml}$ of MilliQ water before application of the samples. At that point $40 \mu \mathrm{l}$ of $60 \mu \mathrm{M}$ dimethoxybenzoic acidDMBA (Sigma-Aldrich) — were added to each sample as the internal standard. The cartridges were washed with $4 \mathrm{ml}$ of MilliQ water and then retained phenolics were eluted out using $3 \mathrm{ml}$ of $96 \%$ methanol. The extracts were evaporated under nitrogen and the resulted solids were dissolved in $1.5 \mathrm{ml}$ of $75 \%$ methanol.

\section{LC/UV and LC/ESI/MS analysis}

LC/UV analyses were performed on the MerckHitachi HPLC system equipped with the L-7100 gradient pump, L-7450 UV detector and L-7200 sequential autosampler. Five microliters of each sample were injected onto RP C-18 column $(250 \times$ $2 \mathrm{~mm}$ ) (Merck) using $2 \mathrm{ml} / \mathrm{min}$ flow rate. Elution was carried out using two solvent mixtures: A $\left(95 \% \mathrm{H}_{2} \mathrm{O} /\right.$ $\left.4.5 \% \mathrm{CH}_{3} \mathrm{CN} / 0.5 \% \mathrm{HCOOH} \mathrm{v} / \mathrm{v} / \mathrm{v}\right)$ and $\mathrm{B}(95 \%$ $\mathrm{CH}_{3} \mathrm{CN} / 4.5 \% \mathrm{H}_{2} \mathrm{O} / 0.5 \% \mathrm{HCOOH}$ v/v/v). The elution steps were as follows: $0-2 \mathrm{~min}-20 \%$ solution A and $80 \%$ solution B, 2-30 min-linear gradient from $20 \%$ solution A to $100 \%$ solution B, 30-45 min$100 \%$ solution B. For the LC/ESI/MS analyses the chromatograph was coupled to a mass spectrometer equipped with an electrospray ion source (WatersMicromass). Nitrogen was used both as the drying and auxiliary gas. The elution protocol was the same as the one used for the LC/UV analysis (see above). Phenolic compounds present in the consecutive samples were identified by their retention times (DMBA was used as the internal standard) or their structures (tentatively elucidated on the basis of the registered mass spectra).

\section{Identification of compound no. 7}

For extraction $500 \mathrm{~g}$ of fresh young leaves were homogenized and extracted in 51 of $80 \% \mathrm{CH}_{3} \mathrm{OH}$ and the resulted solution was concentrated under vacuum to approximately $5 \mathrm{ml}$. The obtained sample was further purified and concentrated using solid phase extraction (SPE) (see above). The sequential fractions of metabolites were eluted with the concentration gradient of methanol (from 10 to $80 \%$ ). Metabolite content in the consecutive fractions was estimated using the thin layer chromatography (TLC). TLC was carried out on cellulose plates using the following solvent: $\mathrm{HCH}_{2} \mathrm{COOC}_{2} \mathrm{H}_{5} / \mathrm{H}_{2} \mathrm{O} / \mathrm{HCH}_{2} \mathrm{OH} / \mathrm{NH}_{3}$ in a ratio of 12/3/3/0.5 (v/v/v/v). The plates were examined under UV after fuming with $\mathrm{NH}_{3}$. The fractions in which compound no. 7 was detected were pooled together and further purified by HPLC on RP C-18 column (the chromatographic conditions are described above). The extracts were evaporated under nitrogen and the resulted solids were diluted in $1.5 \mathrm{ml}$ of $75 \%$ methanol. The LC/UV and LC/ESI/MS analyses were performed as described above.

\section{Quantitation of the identified compounds}

The relative amount of a given compound was estimated using LC/UV chromatograms and expressed as the ratio between the pick area of this compound and the pick area of the standard (DMBA). For a given pair of compounds the ratio of their relative amounts was also calculated.

\section{Expression analysis of PAL genes}

The plant material was collected in 2003 from both experimental locations-Węgrzce and Wieliczka (see above). The samples were picked up in July-when the second generation of carrot fly was active and in September-just before the root harvest. Each sample contained $2 \mathrm{~g}$ of the youngest leaves from 21 plants of a given accession (Table 1). The samples were frozen in liquid nitrogen and stored at $-80{ }^{\circ} \mathrm{C}$ until RNA isolation.

\section{RNA isolation}

The leaf tissue was ground in liquid nitrogen using mortar and pestle, transferred into $50 \mathrm{ml}$ centrifuge 
tubes and immediately supplemented with $16 \mathrm{ml}$ of solution D from the Chomczyński and Sacchi (1987) procedure. After vigorous mixing $1.6 \mathrm{ml}$ of $2 \mathrm{M}$ sodium acetate ( $\mathrm{pH} 4), 16 \mathrm{ml}$ of water-saturated phenol and $3.2 \mathrm{ml}$ of chloroform:isoamyl alcohol (49:1 v/v) were added and the samples were again shaken thoroughly. The preparations were kept in ice for $15 \mathrm{~min}$ and then centrifuged at $22,000 \times g$ for $20 \mathrm{~min}$ in $4{ }^{\circ} \mathrm{C}$. The upper (aqueous) phase was transferred into new tubes and supplemented with $16 \mathrm{ml}$ of chloroform:isoamyl alcohol $(49: 1 \mathrm{v} / \mathrm{v})$. The resulting samples were again vigorously mixed and centrifuged as previously. The aqueous phase was again transferred into new tubes and an equal volume of isopropanol was added. The mixture was shaken gently till the white precipitate became visible. After one-hour incubation in ice the samples were centrifuged as previously, the resulting pellets were washed with $80 \%$ ethanol and again centrifuged $\left(22,000 \times g, 10 \mathrm{~min}, 4^{\circ} \mathrm{C}\right)$. The supernatant was discarded while the pellet was dried under vacuum and dissolved in sterile MilliQ water. The resulted samples were transferred into $1.5 \mathrm{ml}$ Eppendorf tubes, kept in ice for 2 hours and then centrifuged at $24,000 \times g$ for $10 \mathrm{~min}$ in $4{ }^{\circ} \mathrm{C}$. The supernatant was transferred into new Eppendorf tubes and supplemented with $1 / 3$ volume of $8 \mathrm{M} \mathrm{LiCl}$ (the final concentration of $\mathrm{LiCl}$ was $2 \mathrm{M}$ ). The samples were mixed well by inversion and left in $4{ }^{\circ} \mathrm{C}$ for at least $18 \mathrm{~h}$ to allow RNA precipitation. The RNA precipitate was collected by centrifugation at $22,000 \times g$ for $15 \mathrm{~min}$ in $4{ }^{\circ} \mathrm{C}$. The resulting pellets were washed first with $2 \mathrm{M} \mathrm{LiCl}$ and then with $80 \%$ ethanol. Either of the washing steps was followed by centrifugation $\left(24,000 \times g\right.$ for $15 \mathrm{~min}$ in $\left.4{ }^{\circ} \mathrm{C}\right)$. Finally, the RNA pellets were vacuum-dried, dissolved in sterile MilliQ water and stored at $-80{ }^{\circ} \mathrm{C}$. RNA concentration was assessed on the basis of the $\mathrm{A}_{260}$ measurement.

\section{Probe preparation}

The hybridization probes were synthesized using a two step PCR procedure. The primers for DNA amplification were designed on the basis of sequence records for the carrot genes: PAL1, PAL3 and $18 S$ rRNA (Table 2). In the primary PCR, $25 \mu \mathrm{l}$ of the reaction mixture contained: $10 \mathrm{mM}$ TrisHCl pH 8.8, $50 \mathrm{mM} \mathrm{KCl}$, $0.08 \%$ NP-40, $2 \mathrm{mM} \mathrm{MgCl}_{2}, 0.4 \mathrm{mM}$ each dNTP, $0.8 \mu \mathrm{M}$ each primer, $0.5 \mathrm{U}$ of recombinant Taq polymerase (Fermentas) and $15 \mathrm{ng}$ of carrot genomic DNA. The reactions were carried out in the Eppendorf
Mastercycler Gradient programmed for $5 \mathrm{~min}$ at $94{ }^{\circ} \mathrm{C}, 35$ cycles of: $45 \mathrm{~s}$ at $92^{\circ} \mathrm{C}, 45 \mathrm{~s}$ at $57^{\circ} \mathrm{C}$, $2 \mathrm{~min}$ at $72{ }^{\circ} \mathrm{C}$ followed by $10 \mathrm{~min}$ at $72{ }^{\circ} \mathrm{C}$. The amplified fragments were gel-purified using QIAquick PCR Purification Kit (Qiagen), diluted 100-fold and used as a template in the secondary PCR. These reactions were carried out in $50 \mu$ containing: $1 \times$ PCR buffer (Qiagen), $2 \mathrm{mM} \mathrm{MgCl}_{2}, 0.05 \mathrm{mM}$ dATP, $0.05 \mathrm{mM}$ dGTP, $0.05 \mathrm{mM}$ dCTP, $0.034 \mathrm{mM}$ dTTP, $0.016 \mathrm{mM}$ DIG-11-dUTP (Roche), $0.25 \mu \mathrm{M}$ each primer, 1.6 U of HotStarTaq (Qiagen) and $5 \mu \mathrm{l}$ of the diluted primary PCR product (see above). The temperature profile was as in the primary reaction except initial denaturation, which was extended to $15 \mathrm{~min}$. The PCR products of both reactions were monitored by electrophoresis in a standard agarose gel.

\section{Northern hybridization}

Forty micrograms of RNA were brought to $4 \mu \mathrm{l}$ with sterile MilliQ water and supplemented with $16 \mu \mathrm{l}$ of denaturation solution ( $10 \mu \mathrm{l}$ of formamide, $3.3 \mu \mathrm{l}$ of $38 \%$ formaldehyde, $1.7 \mu \mathrm{l}$ of $10 \times$ MOPS and $1 \mu \mathrm{l}$ of sterile MilliQ $\mathrm{H}_{2} \mathrm{O}$ ). The samples were mixed well and incubated in a thermal cycler at $65{ }^{\circ} \mathrm{C}$ for $10 \mathrm{~min}$ and then in ice for $5 \mathrm{~min}$. Prior to electrophoresis $2 \mu \mathrm{l}$ of $6 \times$ Loading Dye Solution (Fermentas) supplemented with ethidium bromide $(1 \mathrm{mg} / \mathrm{ml})$ was added to each sample. The RNAs were separated for $2 \mathrm{~h}$ in $1.5 \%$ agarose containing $2 \%$ formaldehyde. Electrophoresis was carried out in $1 \times$ MOPS buffer (20 mM MOPS, $5 \mathrm{mM}$ sodium acetate, $1 \mathrm{mM}$ EDTA, $\mathrm{pH} 7$ ) at $2 \mathrm{~V} / \mathrm{cm}$ in $4{ }^{\circ} \mathrm{C}$. With the use of $20 \times \mathrm{SSC}$ buffer the RNA separations were capillary-blotted onto positively charged nylon membranes (Roche) and then UV-crosslinked according to standard procedures (Sambrook and Russell 2001). The blots were pre-hybridized for $1 \mathrm{~h}$ at $65{ }^{\circ} \mathrm{C}$ in the Roche standard hybridization buffer and subsequently hybridized overnight at the same temperature with a given DIG-labelled PCR product (see above). The hybridization solution contained $15 \mathrm{ml}$ of the standard hybridization buffer supplemented with $45 \mu$ of the secondary post-PCR mixture. Post-hybridization washes and signal detection were performed according to DIG Application Manual for Filter Hybridization (Roche Diagnostics 2000). Finally, the membranes were exposed to an X-ray film (NBX, Zarys) for 10, 20, 60 and $240 \mathrm{~min}$. Optical density of 
Table 2 Primers used for probe synthesis

\begin{tabular}{lllll}
\hline Gene & Literature reference & Sequence record & Sequence $\left(5^{\prime} \rightarrow 3^{\prime}\right)$ & Amplicon length [bp] \\
\hline PAL1 & Takeda et al. 1997 & D85850 & $\begin{array}{l}\text { gga ttg tga gaa caa gaa tg } \\
\text { tct gca gag cac cac ctt gt } \\
\text { ctt gaa tgc tgg aat att cg }\end{array}$ & 362 \\
PAL3 & Ozeki et al. 2003 & AB089813 & $\begin{array}{l}\text { ttc cat gac tgg aga cac tc } \\
\text { cta gta agc gcg agt cat ca }\end{array}$ & 221 \\
$18 S$ rRNA & Yokota et al. 1989 & X17534 & aat gat cct tcc gca ggt tc & \\
\hline
\end{tabular}

the hybridization signals was quantified using Gene Profiler v. 403 (Scananalytics).

\section{Results}

Variation in plant material susceptibility

In the three-year field experiment carried out in Weqgrzce, 29 carrot accessions were tested (Table 3). Only DC 96367 was examined twice-in 2002 and 2003. The mean percentage of damaged roots ranged from 4.7 to 44.9 and the resistance index-from 86.2 to 99.6. Both measures of carrot infestation were correlated, the Pearson coefficient had the value of -0.87 (negative correlation). Differences observed among the studied accessions with respect to the percentage of damaged roots and resistance index were found to be statistically significant. Line 7262A turned out to be the most resistant-its percentage of damaged roots reached 4.7 and resistance index99.6. The most susceptible were: line OZ with the highest percentage of root damage (44.9) and line AS884 with the lowest resistance index (86.2) (Table 3). Nevertheless, significant genotype-environment interaction was observed (Table 4). Differences in the root damage observed in Węgrzce among the subsequent years were also statistically significant. The respective values reached 24.6, 45.9 and 19.9 in 2001, 2002 and 2003, respectively (Table 3).

In 2002 and 2003 a subset of the accessions analyzed in Wegrzce was also tested in Wieliczka. The subset consisted of ten accessions (Table 1) which according to the first year data from Wegrzce sampled the whole range of phenotypic variation-from strong through moderate susceptibility to resistance. In Wieliczka the mean percentage of damaged roots ranged from 28.0 to 58.3 and the resistance index-from 81.5 to 92.4 . The differences observed between the studied accessions with respect to these both parameters were statistically significant. The lowest percentage of damaged roots was noted for line 2163B and the highest resistance index-for line DC 96367. Satrija with $58.3 \%$ of damaged roots and Karotan with the resistance index reaching only 81.5 were the most susceptible accessions. In the Wieliczka trial the percentage of damaged roots and resistance index were highly correlative with the Pearson coefficient of -0.9 (negative correlation). Year-to-year differences in the root damage were also statistically significant. The respective values reached 64.5 and $33 \%$ in 2002 and 2003, respectively (Table 3). No significant interaction between genotypes and environments was observed for the percentage of damaged roots. For the resistance index this interaction was significant only at $P=0.05$ (Table 4).

Both experimental series (Węgrzce, Wieliczka) were accordant with respect to the resistant behavior of the three accessions: DC 96367, 7262A and 2163B. The relative rank of the seven remaining accessions was to some extent dependent on the experimental location. Both locations were significantly different in the overall extent of infestation-it reached 27 and $48.7 \%$ of damaged roots in Węgrzce and Wieliczka, respectively. The combined calculations performed for both field locations confirmed that in comparison to 2003 , year 2002 was over two-fold more provocative in terms of carrot fly activity (Table 3 ). We did not observe significant interaction between the genotypes and experimental locations as well as between the genotypes and years (Table 4). These interactions had no effect on both the percentage of damaged roots and resistance index.

\section{Phenolic content}

This study was performed for four accessions differing in the estimated tolerance to the Psila rosae root damage: Dolanka, Karotan, 7262A and DC 96367. 
Table 3 Parameters of carrot fly infestation noted for the carrot accessions tested in the field experiments located in Węgrzce and Wieliczka

\begin{tabular}{|c|c|c|c|c|c|c|}
\hline \multirow[t]{2}{*}{ Accession } & \multicolumn{2}{|c|}{ Węgrzce (2001-2003) } & \multicolumn{2}{|c|}{ Wieliczka (2002-2003) } & \multicolumn{2}{|c|}{$\begin{array}{l}\text { Węgrzce, Wieliczka } \\
(2002-2003)\end{array}$} \\
\hline & $\begin{array}{l}\% \text { of damaged } \\
\text { roots }\end{array}$ & $\begin{array}{l}\text { Resistance } \\
\text { index }\end{array}$ & $\begin{array}{l}\% \text { of damaged } \\
\text { roots }\end{array}$ & $\begin{array}{l}\text { Resistance } \\
\text { index }\end{array}$ & $\begin{array}{l}\% \text { of damaged } \\
\text { roots }\end{array}$ & $\begin{array}{l}\text { Resistance } \\
\text { index }\end{array}$ \\
\hline $\mathrm{OZ}$ & 44.9 & 86.7 & - & - & - & - \\
\hline AS884 & 43.6 & 86.2 & - & - & - & - \\
\hline 10138B & 41.3 & 90.0 & - & - & - & - \\
\hline 9370B & 42.8 & 86.5 & - & - & - & - \\
\hline DC 96280 & 41.3 & 89.6 & 41.2 & 81.9 & 41.7 & 83.5 \\
\hline Satrija & 40.8 & 89.1 & 58.3 & 83.3 & 50.5 & 85.2 \\
\hline Dolanka & 38.1 & 86.4 & 45.0 & 84.4 & 43.8 & 84.4 \\
\hline DC 84022 & 36.7 & 86.8 & 51.5 & 84.4 & 47.2 & 84.4 \\
\hline $9370 \times 2158$ & 34.3 & 88.7 & - & - & - & - \\
\hline $2874 \times \mathrm{R} 92$ & 33.4 & 89.1 & - & - & - & - \\
\hline $10138 \times 52257 \mathrm{Fe}$ & 31.3 & 89.5 & - & - & - & - \\
\hline $1028 \times 9370 \mathrm{~B}$ & 30.8 & 91.0 & - & - & - & - \\
\hline DC 79002 & 30.4 & 90.7 & 46.5 & 84.6 & 39.9 & 87.4 \\
\hline $52274 \mathrm{Fe}$ & 28.9 & 91.2 & - & - & - & - \\
\hline $9370 \mathrm{~A}$ & 28.7 & 88.9 & - & - & - & - \\
\hline $2163 \mathrm{~A}$ & 27.7 & 92.6 & - & - & - & - \\
\hline $7262 B$ & 27.2 & 94.5 & 49.0 & 84.3 & 41.0 & 88.0 \\
\hline 2158 & 26.8 & 92.4 & - & - & - & - \\
\hline $2874 \mathrm{~A}$ & 26.2 & 93.2 & - & - & - & - \\
\hline $10138 \mathrm{~A}$ & 25.6 & 92.3 & - & - & - & - \\
\hline Karotan & 25.5 & 91.6 & 52.4 & 81.5 & 42.0 & 85.4 \\
\hline $1028 \mathrm{~A}$ & 25.2 & 93.9 & - & - & - & - \\
\hline 2874B & 24.8 & 90.9 & - & - & - & - \\
\hline 1028B & 24.5 & 93.9 & - & - & - & - \\
\hline $2163 \times 2158$ & 21.1 & 93.7 & - & - & - & - \\
\hline $2163 \times$ NAS & 19.5 & 94.2 & - & - & - & - \\
\hline 2163B & 17.6 & 92.3 & 28.0 & 89.9 & 23.9 & 91.3 \\
\hline DC $96367 *$ & 10.8 & 95.9 & 29.3 & 92.4 & 20.5 & 94.1 \\
\hline $7262 \mathrm{~A}$ & 4.7 & 99.6 & 33.8 & 89.7 & 21.3 & 93.6 \\
\hline $\operatorname{LSD}(P=0.05)$ & 14.28 & 5.88 & 14.15 & 5.31 & 12.80 & 5.16 \\
\hline $\begin{array}{l}\text { Correlation coefficient } \\
\text { (Pearson) }\end{array}$ & -0.87 & & -0.9 & & -0.84 & \\
\hline \multicolumn{7}{|l|}{ Means for } \\
\hline 2001 & 24.6 & 92.5 & - & - & - & - \\
\hline 2002 & 45.9 & 85.3 & 64.5 & 77.2 & 55.4 & 80.3 \\
\hline 2003 & 19.9 & 94.7 & 33.0 & 89.9 & 25.1 & 92.4 \\
\hline \multicolumn{7}{|c|}{ Means for 10 accessions tested in both locations } \\
\hline Węgrzce & & & & & 27.0 & 91.0 \\
\hline Wieliczka & & & & & 48.7 & 83.5 \\
\hline $\operatorname{LSD}(P=0.05)$ & & & & & 5.72 & 2.36 \\
\hline
\end{tabular}

\footnotetext{
* In Weqgrzce line DC 96367 was tested only in 2002 and 2003 (the remaining accessions were tested in 2001, 2002 and 2003)
} 
Table 4 Results of variance analysis applied to the percentage of damaged roots and resistance index for the carrot accessions tested in Węgrzce and Wieliczka

\begin{tabular}{|c|c|c|c|c|c|c|}
\hline \multirow[t]{2}{*}{ Field trials } & \multirow[t]{2}{*}{ Source } & \multirow[t]{2}{*}{ df } & \multicolumn{2}{|c|}{$\%$ of damaged roots } & \multicolumn{2}{|c|}{ Resistance index } \\
\hline & & & MS & F-value & MS & F-value \\
\hline \multirow[t]{4}{*}{ Węgrzce 2001-2003 } & Year (Y) & 2 & $10,346.10$ & $70.20 * *$ & $1,397.49$ & $55.61 * *$ \\
\hline & Genotype (G) & 28 & 576.83 & $3.91 * *$ & 58.55 & $2.33 * *$ \\
\hline & $\mathrm{G} \times \mathrm{Y}$ & 56 & 387.4 & $2.63 * *$ & 43.70 & $1.74 *$ \\
\hline & Error & 87 & 147.38 & & 25.13 & \\
\hline \multirow[t]{4}{*}{ Wieliczka 2002-2003 } & Year $(Y)$ & 1 & $13,164.77$ & $56.03 * *$ & $2,125.62$ & $64.24 * *$ \\
\hline & Genotype (G) & 9 & 629.70 & $2.68 *$ & 81.81 & $2.47 *$ \\
\hline & $\mathrm{G} \times \mathrm{Y}$ & 9 & 375.33 & $1.60^{\mathrm{ns}}$ & 72.91 & $2.20^{*}$ \\
\hline & Error & 40 & 234.97 & & 33.09 & \\
\hline \multirow[t]{8}{*}{ Węgrzce, Wieliczka 2002-2003 } & Year (Y) & 1 & $22,028.57$ & $114.56 * *$ & $3,524.91$ & $112.67 * *$ \\
\hline & Locations (L) & 1 & $6,939.80$ & $36.09 * *$ & 822.05 & $26.28 * *$ \\
\hline & Genotype (G) & 9 & 1214.09 & $6.31 * *$ & 116.44 & $3.72 * *$ \\
\hline & $\mathrm{Y} \times \mathrm{L}$ & 1 & 5116.13 & $26.60 * *$ & 714.93 & $22.85 * *$ \\
\hline & $\mathrm{Y} \times \mathrm{G}$ & 9 & 200.93 & $1.04^{\mathrm{ns}}$ & 62.47 & $1.99^{\mathrm{ns}}$ \\
\hline & $\mathrm{L} \times \mathrm{G}$ & 9 & 318.61 & $1.66^{\mathrm{ns}}$ & 27.16 & $0.87^{\mathrm{ns}}$ \\
\hline & $\mathrm{Y} \times \mathrm{L} \times \mathrm{G}$ & 9 & 820.51 & $4.27 * *$ & 102.00 & $3.26 * *$ \\
\hline & Error & 60 & 192.29 & & 31.28 & \\
\hline
\end{tabular}

ns not significant

** Significant at the 0.01 probability level

* Significant at the 0.05 probability level

The phenolic content was investigated in young and mature (old) leaves-both were collected in July and September from the plants grown in Wegrzce and Wieliczka. The use of liquid chromatography coupled with mass spectrometry enabled identification of six phenolic compounds. These were: chlorogenic acid as well as glycosides of flavonoids-luteolin (two types), methyluteolin, apigenin and kaempferol (Table 5). The identity of one compound (compound no. 7) was not elucidated. However, the coupled use of liquid chromatography/mass spectrometry (LC/MS) with electrospray ionization (ESI) (Bednarek et al. 2001, Stobiecki and Kachlicki 2006) identified three constituents of that compound: chinolic acid, glucose and caffeic acid methyl ester (Fig. 1).

Relative quantity of the identified compounds was calculated from the LC/UV spectra and expressed as the ratio between the peak area of each compound and that of the standard (dimethoxybenzoic acid-DMBA). The calculated differences in accumulation of the identified compounds were not significant among the studied accessions. Moreover, no correlation was observed between the content of these phenolics and the resistance/susceptibility character of the examined accessions. However, upon closer examination of the accumulation data some specific relationships were noted. We found that in young leaves compound no. 7 was the highest accumulated among the identified phenolics (Fig. 2). In mature leaves accumulation of this compound was reduced and therefore, the phenolic content was dominated by luteolin-7- $O$-glucoside, although contribution of the latter in relation to the other studied compounds did not change with the age of the leaves. The difference between young and mature leaves in accumulation of the compound no. 7 was evident regardless of the date of leaf harvest (July, September) and experimental location (Węgrzce, Wieliczka). We have also looked at accumulation ratios of the studied phenolics and found an interesting correlation for the following two proportions: luteolin-7-Oglucoside/kaempferol-3-O-glucoside and methyluteoline-7-O-glucoside/kaempferol-3-O-glucoside. In case of the mature (old) leaves collected in July both ratios were evidently higher for the resistant lines (7262A, DC 96367). This observation was accordant for both experimental localities-Węgrzce and Wieliczka 
Table 5 Phenolic compounds detected in carrot leaves with the use of LC/UV, LC/MS and LC/ESI/MS

\begin{tabular}{|c|c|c|c|}
\hline Compound & $\begin{array}{l}\text { Elemental } \\
\text { formula }\end{array}$ & $\begin{array}{l}\text { Retention } \\
\text { time }\left(\mathrm{t}_{\mathrm{r}}\right) \\
{[\mathrm{min}]}\end{array}$ & $\begin{array}{l}\text { Molecular } \\
\text { mass }\left(\mathrm{M}_{\mathrm{r}}\right)\end{array}$ \\
\hline Chlorogenic acid & $\mathrm{C}_{16} \mathrm{H}_{18} \mathrm{O}_{9}$ & 7.0 & 354 \\
\hline $\begin{array}{l}\text { Luteolin-7-O- } \\
\text { glucoside }^{\mathrm{a}}\end{array}$ & $\mathrm{C}_{21} \mathrm{H}_{20} \mathrm{O}_{11}$ & 26.5 & 448 \\
\hline $\begin{array}{l}\text { Methyluteolin-7-O- } \\
\text { glucoside }^{\text {b }}\end{array}$ & $\mathrm{C}_{22} \mathrm{H}_{22} \mathrm{O}_{11}$ & 27.5 & 462 \\
\hline $\begin{array}{l}\text { Luteolin-7-O-(6'- } \\
\text { malonyl)- } \\
\text { glucoside }^{\mathrm{b}}\end{array}$ & $\mathrm{C}_{24} \mathrm{H}_{22} \mathrm{O}_{14}$ & 35.1 & 534 \\
\hline $\begin{array}{l}\text { Apigenin-7-O- } \\
\text { glucoside }^{\mathrm{a}}\end{array}$ & $\mathrm{C}_{21} \mathrm{H}_{20} \mathrm{O}_{10}$ & 32.9 & 432 \\
\hline $\begin{array}{l}\text { Kaempferol-3-O- } \\
\text { glucoside }^{\text {b }}\end{array}$ & $\mathrm{C}_{21} \mathrm{H}_{20} \mathrm{O}_{11}$ & 34.1 & 448 \\
\hline Compound no. 7 & - & 47.0 & 568 \\
\hline
\end{tabular}

${ }^{a}$ Identified by comparison with the standard

b Identified tentatively

(Fig. 3). For the samples collected in September this correlation was not evident (data not shown).

Accumulation of PAL mRNAs

Expression of PAL genes was studied for the four accessions examined also with respect to the phenolic content-Dolanka, Karotan, 7262A and DC 96367. Leaf samples were collected form both experimental locations (Węgrzce, Wieliczka) in July and September. In all examined samples a single signal was observed for both PAL1 and PAL3 probe. The transcript sizes were estimated at 3.0 and $3.5 \mathrm{~kb}$ for
PAL1 and PAL3, respectively. Accumulation of both mRNAs varied with the tested accessions, time of leaf sampling and field location (Fig. 4).

Among the samples collected in July at Weggrzce the PAL1 mRNA was observed at low level for Dolanka, for 7262A and DC 96367 the respective signal was barely visible and in case of Karotan it was not detected. The $P A L 3$ transcripts were detected in all tested accessions but at the very low level requiring 4-hour exposure of the $\mathrm{X}$-ray film. The hybridization signals of the PAL3 mRNA were slightly higher in Dolanka and Karotan than in 7262A and DC 96367. A different situation was observed for the samples collected in September. The highest accumulation of both transcripts was detected in DC 96367. The signals recorded for 7262A were approximately five-fold weaker than those of DC 96367 and distinctly stronger than those observed for Dolanka and Karotan. Among the samples collected in July at Wieliczka the highest expression of both transcripts was observed for DC 96367. Line 7262A exhibited approximately six-fold lower accumulation of either mRNA. In the samples of Dolanka and Karotan the studied mRNA species were not detected. In all Wieliczka samples collected in September accumulation of both PALI and PAL3 mRNA was observed. The strongest hybridization signals were obtained for lines 7262A and DC 96367 while the weakest ones for Dolanka (Fig. 4).

\section{Discussion}

Our results demonstrate that the studied carrot accessions exhibit significant differences with respect to the
Fig. 1 Total ion chromatogram (LC/MS) of compound no. 7 isolated from carrot leaves

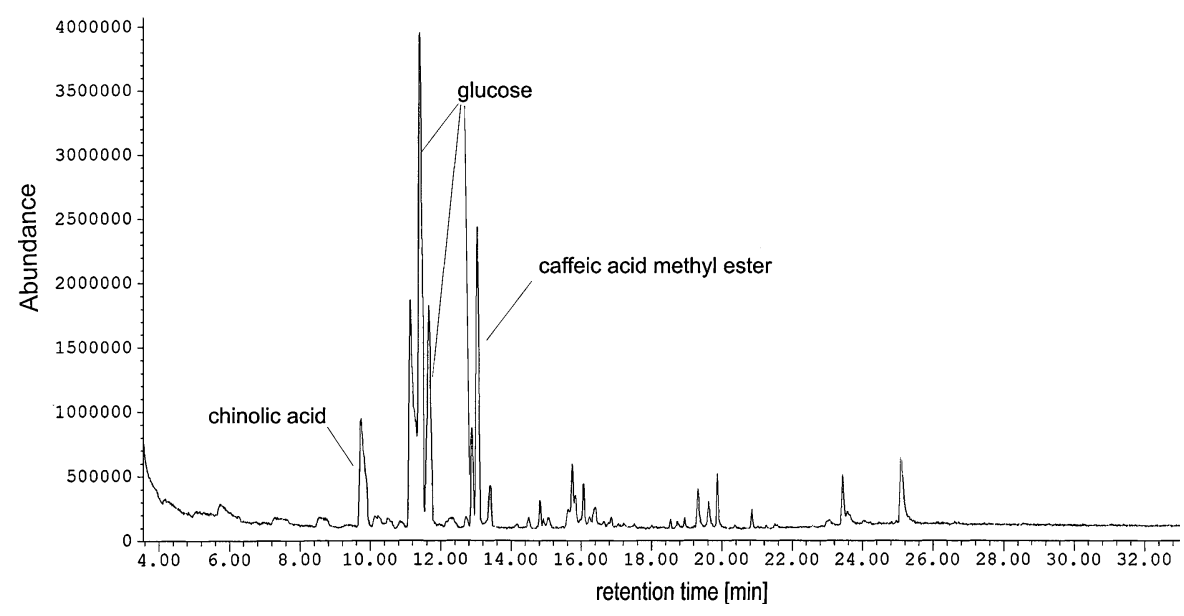


Fig. 2 LC/UV

chromatograms of phenolics extracted from young (a) and old (b) carrot leaves
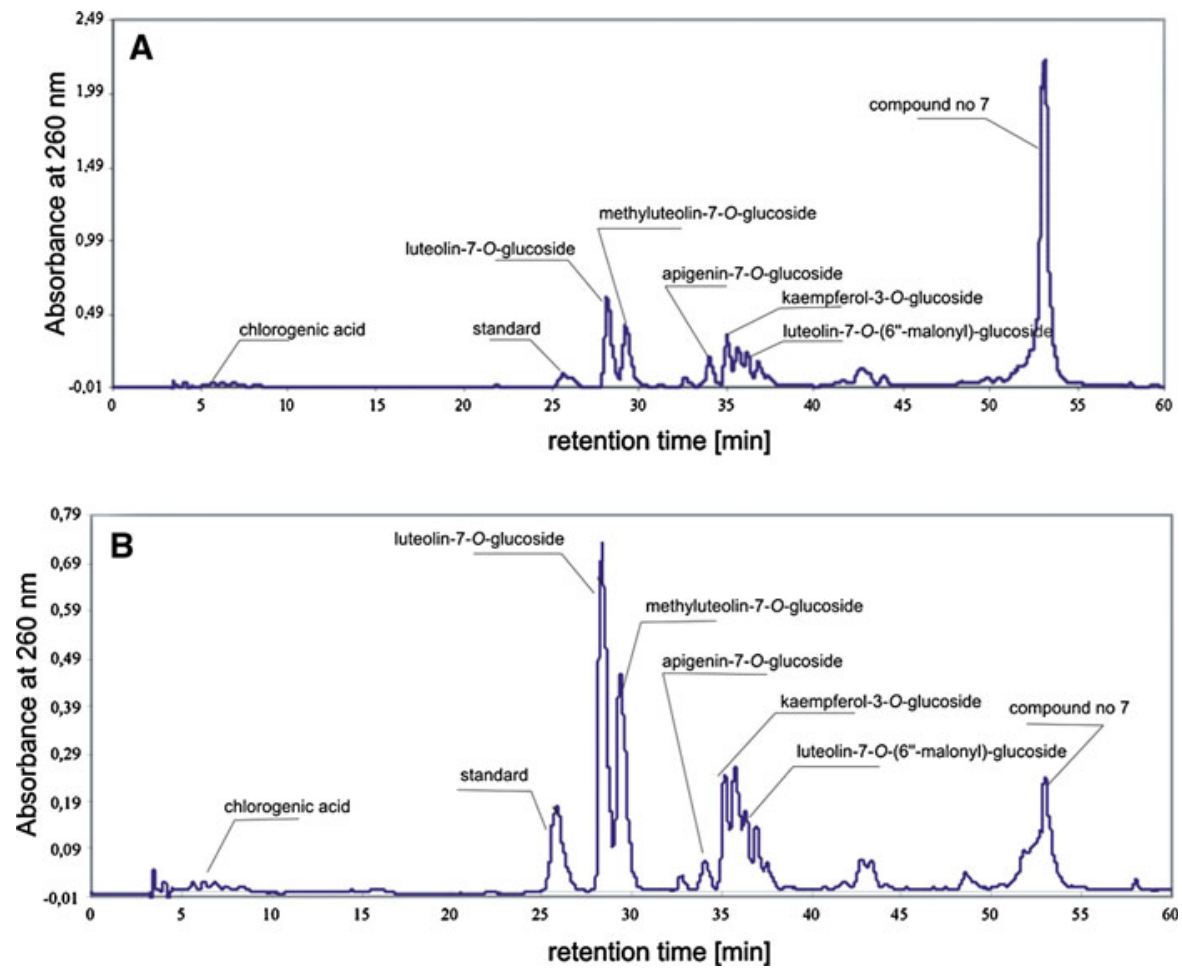

carrot fly damage. The field experiments were carried out for three years in two different locations. Both time and location of experiments strongly influenced the overall level of root damage. Nevertheless, it was possible to point out some accessions that in these diverse environmental conditions consistently exhibited either high or low level of resistance. The most resistant were DC 96367, 7262A and 2163B. Line 2163 has an orange root color. DC 96367 exhibits a range of root colors-from white through yellow to orange. It was derived from a cross between Daucus glochidiatus and cultivated carrot in the program carried out by the Wellesbourne group. Former experiments had shown that $D$. glochidiatus was highly resistant to carrot fly larval damage (Ellis 1999). Line 7262 was derived from a cross between the Turkish accession PI 173687, which had highly variable root colors, and the dark orange inbred derived from Danvers 126. Line 7262 has typical dark purple roots with orange colored phloem, cambium and xylem (Simon et al. 1997). Our data indicate that male-sterile line $7262 \mathrm{~A}$ is more resistant than its fertile counterpart 7262B. At present it is difficult to judge if it is related to the different cytoplasmic composition of $7262 \mathrm{~A}$ and $7262 \mathrm{~B}$ or if it reflects their yet not fully isogenic character. In the Węgrzce trial also five other $\mathrm{A} / \mathrm{B}$ pairs were examined. Interestingly, the resistance index of the petaloid CMS lines (2163A, 2874A, $7262 \mathrm{~A}, 9370 \mathrm{~A})$ was higher than that of their maintainers $(2163 \mathrm{~B}, 2874 \mathrm{~B}, 7262 \mathrm{~B}, 9370 \mathrm{~B})$. These data indicate that indeed the plasmotype has some effect on carrot resistance to $P$. rosae. Consistently good performance of DC 96367 and 7262A prompted us to use them as the resistance representatives in our chemical and molecular analysis. In terms of practical importance these data indicate that in addition to the well-known Wellesbourne DC 96367 source also line 7262 can be used for introgression of resistance genes in carrot breeding programs. The heaviest root damage was observed for some Polish breeding lines as well as for cultivars Dolanka and Satrija. All this material exhibits a typical orange root color. The high level of root damage was also observed for line DC 96280 which was selected in HRI Wellesbourne from the susceptible cultivar Danvers. DC 79002-another line developed from Danvers and used in Wellesbourne as a susceptible standard (Ellis et al. 1993) — in our experiments showed a low level of root damage which was accordant with the earlier trials carried out in Poland (Legutowska 1991). Such results indicate that 
Fig. 3 Luteolin-7-Oglucoside/kaempferol-3-Oglucoside (a) and methyluteolin-7-Oglucoside/kaempferol-3-Oglucoside (b) accumulation ratios calculated for young and mature (old) leaves collected in July from the selected carrot accessions grown in Weqgrzce and Wieliczka. Values denoted with different letters are significantly different (Duncan's multiple range test, $P=0.05$ ). Standard errors were calculated using the delta method
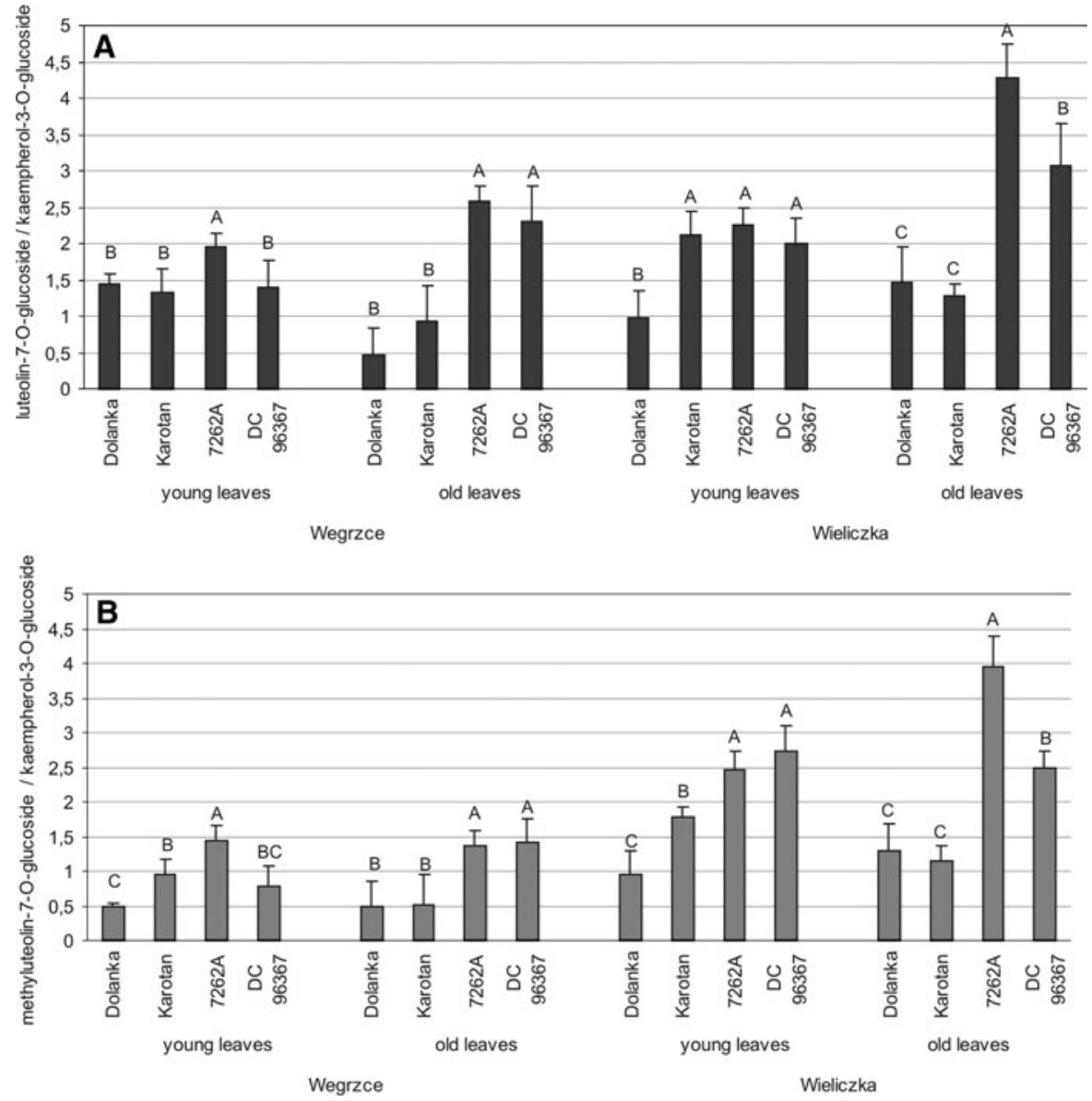

expression of resistance/susceptibility is strongly modulated by environmental conditions which makes breeding efforts very cumbersome-the more so because very little is known about biochemical and molecular aspects of plant pest resistance.

Numerous reports point to secondary metabolites as the main mediators of plant-pest interactions (Harborne 1997). Carrot plants contain a variety of compounds which may act as stimulants or repellents for pests. Our research demonstrated a spectacular change in the content of secondary compounds during carrot growth. The major phenolic compound detected in young leaves was referred to as compound no. 7 which upon ionization in the mass spectrometer decomposed into chinolic acid, glucose and caffeic acid methyl ester. The phenolic content of mature leaves was dominated by luteolin-7-O-glucoside. These observations supplement the data of Kainulainen et al. $(1998,2002)$ who reported changes in accumulation of volatile terpenoids during vegetation of carrot plants. These authors revealed that younger leaves contain more propenylbenzenes, methylisoeugenol and alfa-asarone than older ones. It is also known that composition of volatile compounds on the surface of leaves influences oviposition of carrot fly (Städler and Buser 1984). The content of volatile constituents was also studied for carrot roots (Buttery et al. 1968). In these studies chlorogenic acid was identified as the main phenolic component accumulated in the peel of carrot roots and moreover, a clear relationship was found between its concentration and carrot fly larval damage. Accordingly to this observation cultivars with higher concentration of root chlorogenic acid were more susceptible to larval damage than low content ones (Cole 1985) indicating that resistance was based on antibiosis. In the present study we focused our attention on foliage metabolites which may condition the antixenosis-based plant resistance like e.g. flavonoid glucosides known to act as oviposition stimulants for pests (Harborne 1997; 
Fig. 4 Northern blots of total cellular carrot RNA hybridized with PAL1, PAL3 and $18 S$ rRNA (control) gene probes. The RNAs were isolated from harvested in July and September leaves of the selected accessions grown in Węgrzce and Wieliczka. Exposure times of the X-ray film are shown on the left. For one-hour exposure IntOD of the PALI and $P A L 3$ hybridization signals is indicated

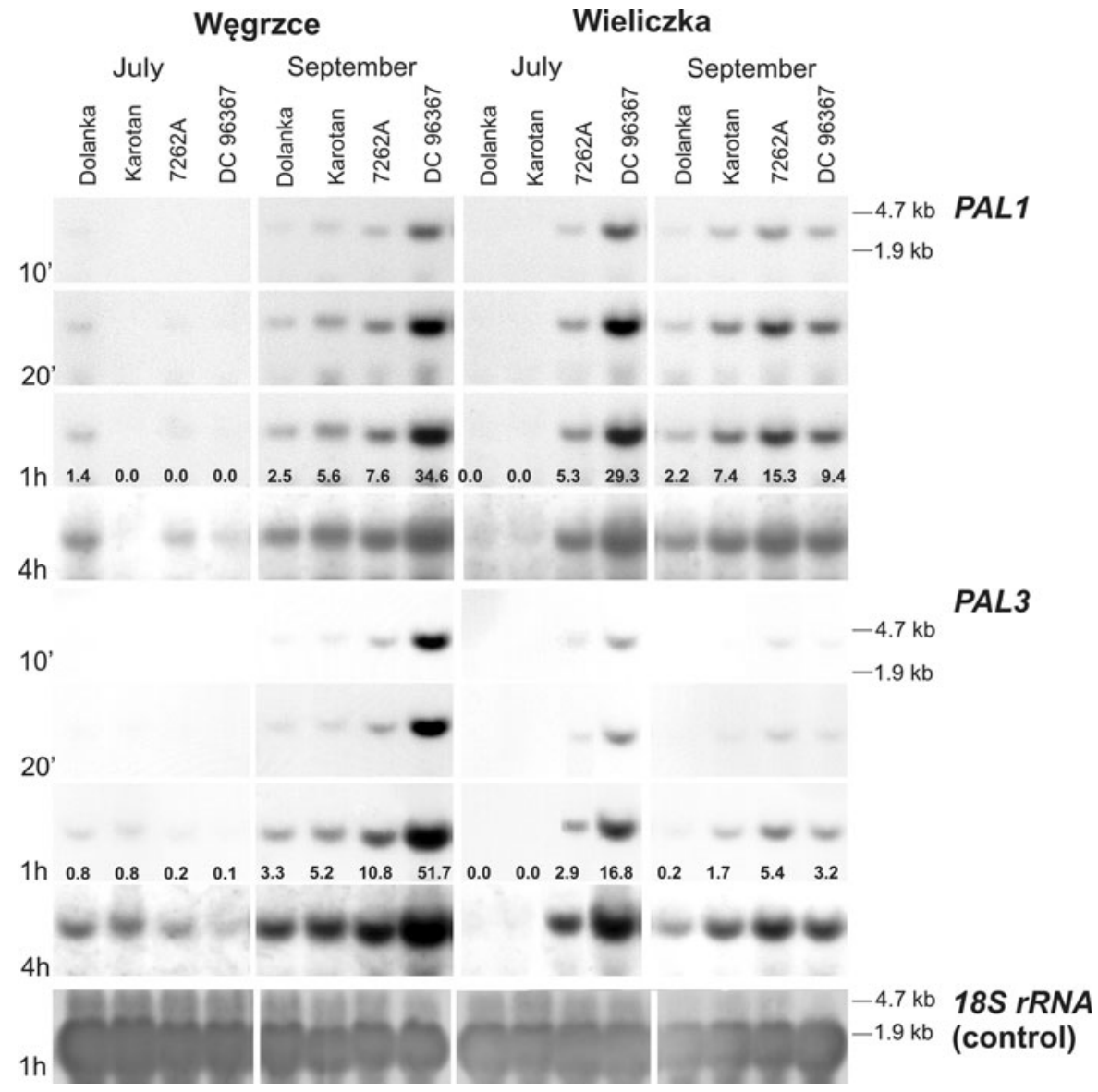

Fulcher et al. 1998; Lattanzio et al. 2000). In our experiments we have identified three flavonoid glucosides (luteolin-7-O-glucoside, kaempferol 3-Oglucoside and methyluteoline-7-O-glucoside) which mutual proportions correlated with the incidence of carrot fly damage. This result is accordant with some earlier reports showing that mixtures of certain compounds emanated from carrot foliage turned out to be more attractive for pests than single compounds (Guerin et al. 1983; Matsuda and Matsuo 1985; Fenny et al. 1988).

A number of genes were shown to be involved in accumulation of secondary metabolites in plant tissues (Hauffe et al. 1991; Logemann et al. 1995; Koopmann et al. 1999). Phenylalanine ammonia-lyase (PAL) catalyzes the first reaction in the biosynthesis of many plant phenylpropanoid compounds. This enzyme is encoded by the family of genes, which can be expressed differentially during plant development and in response to different environmental cues
(Liang et al. 1989, Olsen et al. 2008, Huang et al. 2010). It is also possible that the individual PAL genes are expressed in different sets of cells (Logemann et al. 1995; Kao et al. 2002). In our experiments carrot leaves exhibited similar expression patterns of $P A L 1$ and PAL3 suggesting common regulation of both genes. The respective transcript sizes were different confirming that the detected mRNAs originated from distinct genes. Our data showed that the studied carrot accessions differed in accumulation of the $P A L 1$ and $P A L 3$ mRNAs and that in most cases these differences correlated with the overall tolerance to carrot fly. Generally, the highest expression of both PAL genes was observed in the resistant lines DC 96367 and 7262A. Weaker or barely detectable accumulation of these transcripts was shown for much more susceptible varieties-Dolanka and Karotan. Similar results were reported by Chaman et al. (2003) who found that barley cultivars which were resistant to aphids Schizaphis graminum exhibited elevated expression 
of PAL genes. In addition to the mentioned genotypic differences we also observed temporal dependence of $P A L 1$ and PAL3 expression-in most cases accumulation of both studied mRNAs was higher in September than in July. This observation supports some earlier reports indicating that transcription of PAL genes can be activated by stress factors-especially insect feeding (Leszczyński 1985). According to this interpretation accumulation of the PAL mRNA increases over time in response to stressing environmental factors and among those-wounding caused by the larvae of carrot fly. Both transcription level of the PAL genes and activity of the PAL enzyme were shown to correlate with accumulation of specific secondary metabolites in plants. Chlorogenic acid provides an example of a compound which concentration can be associated with the PAL activity (Leszczyński 1985; Bate et al. 1994; Howles et al. 1996; Shadle et al. 2003). However, despite the observed increased expression of the PAL genes in the resistant accessions, we were not able to indicate any single specific chemical compound which accumulation correlated with the resistant phenotype. It may be related to the above-mentioned chemical complexity of the signals sensed by the pest. This may be also due to the fact that the PAL genes control synthesis of many phenolic compounds and only a few were analyzed in the present work. Therefore, it seems that future studies of plant-insect interactions will require metabolomic approaches which provide information about the entire chemical complement of plant tissues.

Acknowledgments The authors thank Prof. B. Michalik for the valuable comments during this work, revision of the manuscript and for providing the plant material.

Open Access This article is distributed under the terms of the Creative Commons Attribution License which permits any use, distribution, and reproduction in any medium, provided the original author(s) and the source are credited.

\section{References}

Bate NJ, Orr J, Ni W, Meromi A, Nadler-Hassar T, Doerner PW, Dixon RA, Lamb CJ, Elkind Y (1994) Quantitative relationship between phenylalanine ammonia-lyase levels and phenylpropanoid accumulation in transgenic tobacco identifies a rate-determining step in natural product synthesis. Proc Natl Acad Sci USA 91:7608-7612

Bednarek P, Frański R, Kerhoas L, Einhorn J, Wojtaszek P, Stobiecki M (2001) Profiling changes in metabolism of isoflavonoids and their conjugates in Lupinus albus treated with biotic elicitor. Phytochemistry 56:77-85

Buttery RG, Seifert RM, Guadagni DG, Black DR, Ling LC (1968) Characterization of some volatile constituents of carrots. J Agric Food Chem 16:1009-1015

Chaman ME, Copaja SV, Argandona VH (2003) Relationships between salicylic acid content, phenylalanine ammonialyase (PAL) activity, and resistance of barley to aphid infestation. J Agric Food Chem 51:2227-2231

Chomczyński P, Sacchi N (1987) Single-step method of RNA isolation by acid guanidinium thiocyanate-phenol-chloroform extraction. Anal Biochem 162:156-159

Cole RA (1985) Relationship between the concentration of chlorogenic acid in carrot roots and the incidence of carrot fly larval damage. Ann Appl Biol 106:211-217

Delvas N, Bauce É, Labbé C, Ollevier T, Bélanger R (2011) Phenolic compounds that confer resistance to spruce budworm. Entomol Exp Appl 141:35-44

Ellis PR (1999) The identification and exploitation of resistance in carrots and wild Umbelliferae to the carrot fly, Psila rosae (F.). Integr Pest Manage Rev 4:259-268

Ellis PR, Hardman JA (1981) The consistency of the resistance of eight carrot cultivars to carrot fly attack at several centres in Europe. Ann Appl Biol 98:491-497

Ellis PR, Freeman GH, Hardman JA (1984) Differences in the relative resistance of two carrot cultivars to carrot fly attack over five seasons. Ann Appl Biol 105:557-564

Ellis PR, Saw PL, Crowther TC (1991) Development of carrot inbreds with resistance to carrot fly using a single seed descent programme. Ann Appl Biol 119:349-357

Ellis PR, Hardman JA, Crowther TC, Saw PL (1993) Exploitation of the resistance to carrot fly in the wild carrot species Daucus capillifolius. Ann Appl Biol 122:079-091

Fenny P, Sachdev K, Rosenberry L, Carter M (1988) Luteolin 7-O-(6"-O-malonyl)- $\beta$-glucoside and trans-chlorogenic acid: oviposition stimulants for the black swallowtail butterfly. Phytochemistry 27:3439-3448

Finch S (1993) Integrated pest management of the cabbage root fly and the carrot fly. Crop Prot 12:423-430

Fulcher AF, Ranney TG, Burton JD, Walgenbach JF, Danehower DA (1998) Role of foliar phenolics in host plant resistance of Malus taxa to adult Japanese beetles. HortScience 33:862-865

Guerin PM, Städler E, Buser HR (1983) Identification of host plant attractants for the carrot fly, Psila rosae. J Chem Ecol 9:843-861

Harborne JB (1997) Introduction to ecological biochemistry, 4th edn. Academic Press, London

Hauffe KD, Paszkowski U, Schulze-Lefert P, Hahlbrock K, Dangl JL, Dauglas C (1991) A parsley 4CL-1 promoter fragment specifies complex expression patterns in transgenic tobacco. Plant Cell 3:435-443

Honda K, Omura H, Chachin M, Kawano S, Inoue TA (2011) Synergistic or antagonistic modulation of oviposition response of two swallowtail butterflies, Papilio maackii and $P$. protenor, to Phellodendron amurense by its constitutive prenylated flavonoid, phellamurin. J Chem Ecol 37:575-581

Howles PA, Sewalt VJH, Paiva NL, Elkind Y, Bate NJ, Lamb C, Dixon RA (1996) Overexpression of L-phenylalanine ammonia-lyase in transgenic tobacco plants reveals control 
points for flux into phenylpropanoid biosynthesis. Plant Physiol 112:1617-1624

Huang J, Gu M, Lai Z, Fan B, Shi K, Zhou YH, Yu JQ, Chen Z (2010) Functional analysis of the Arabidopsis PAL gene family in plant growth, development, and response to environmental stress. Plant Physiol 153:1526-1538

Kainulainen P, Tarhanen J, Tiilikkala K, Holopainen JK (1998) Foliar and emission composition of essential oil in two carrot varieties. J Agric Food Chem 46:3780-3784

Kainulainen P, Nissinen A, Piirainen A, Tiilikkala K, Holopainen JK (2002) Essential oil composition in leaves of carrot varieties and preference of specialist and generalist sucking insect herbivores. Agric For Entomol 4:211-216

Kao YY, Harding SA, Tsai CJ (2002) Differential expression of two distinct phenylalanine ammonia-lyase genes in condensed tannin-accumulating and lignifying cells of quaking aspen. Plant Physiol 130:796-807

Kimura S, Oyanagi M, Fukuda T, Ohno Y, Hongo C, Itoh Y, Koda T, Ozeki Y (2008) Role of miniature inverted repeat transposable elements inserted into the promoter region of a carrot phenylalanine ammonia-lyase gene and its gene expression. Plant Biotechnol 25:473-481

Koopmann E, Logemenn E, Hahlbrock K (1999) Regulation and functional expression of cinnamate 4-hydroxylase from parsley. Plant Physiol 119:49-56

Lattanzio V, Arpaia S, Cardinali A, Di Venere D, Linsalata V (2000) Role of endogenous flavonoids in resistance mechanism of Vigna to aphids. J Agric Food Chem 48: 5316-5320

Legutowska H (1991) The assessment of carrot susceptibility to carrot fly Psila rosae Fabr., Diptera: Psilidae. Meeting of Polish Vegetable Breeders, Krakow, pp 81-86 (in Polish)

Leszczyński B (1985) Changes in phenols content and metabolism in leaves of susceptible and resistant winter wheat cultivars infested by Rhopalosiphum padi (L.) (Hom. Aphididae). Z Angew Entomol 100:343-348

Liang XW, Dron M, Cramer CL, Dixon RA, Lamb CJ (1989) Differential regulation of phenylalanine ammonia-lyase genes during plant development and by environmental cues. J Biol Chem 264:14486-14492

Logemann E, Parniske M, Hahlbrock K (1995) Modes of expression and common structural features of the complete phenylalanine ammonia-lyase gene family in parsley. Proc Natl Acad Sci USA 92:5905-5909

Matsuda K, Matsuo H (1985) A flavonoid, luteolin 7-glucoside, as well as salicin and populin, stimulating the feeding of leaf-beetles attacking Salicaceaous plants. Appl Entomol Zool 20:305-313

Michalik B, Wiech K (2000) Differences in the resistance of carrot lines and cultivars to carrot fly [Psila rosae (Fabr.)] attack. Folia Horticult 12:43-51

Olsen KM, Lea US, Slimestad R, Verheul M, Lillo C (2008) Differential expression of four Arabidopsis PAL genes; $P A L 1$ and $P A L 2$ have functional specialization in abiotic environmental-triggered flavonoid synthesis. Plant Physiol 165:1491-1499

Olsson K, Svensson R (1997) Are carrot phenols and polyacetylenes influencing susceptibility to storage rots? J Appl Genet 38A:219-223

Ozeki Y, Chikagawa Y, Kimura S, Soh HC, Maeda K, Pornsiriwong W, Kato M, Akimoto H, Oyanagi M, Fukuda T, Koda T, Itoh Y, Yamada A, Davies E, Ueno H, Takeda J (2003) Putative cis-elements in the promoter region of the carrot phenylalanine ammonia-lyase gene induced during anthocyanin synthesis. J Plant Res 116:155-159

Reymond P, Weber H, Damond M, Farmer EE (2000) Differential gene expression in response to mechanical wounding and insect feeding in Arabidopsis. Plant Cell 12:707-719

Sambrook J, Russell DW (2001) Molecular cloning: a laboratory manual, 3rd edn. Cold Spring Harbor Laboratory Press, Cold Spring Harbor

Shadle GL, Wesley SV, Korth KL, Chen F, Lamb C, Dixon RA (2003) Phenylpropanoid compounds and disease resistance in transgenic tobacco with altered expression of L-phenylalanine ammonia-lyase. Phytochemistry 64:153-161

Simon PW, Rubatzky VE, Bassett MJ, Strandberg JO, White JM (1997) B7262, purple carrot inbred. HortScience 32: 146-147

Städler E, Buser HR (1984) Defense chemicals in leaf surface wax synergistically stimulate oviposition by phytophagous insect. Experientia 40:1157-1159

Stobiecki M, Kachlicki P (2006) Isolation and identification of flavonoids. In: Grotewold E (ed) The science of flavonoids, 2nd edn. Springer, New York, pp 47-70

Takeda J, Ozeki Y, Yoshida K (1997) Action spectrum for induction of promoter activity of phenylalanine ammonialyase gene by UV in carrot suspension cells. Photochem Photobiol 66:464-470

Yokota Y, Kawata T, Iida Y, Kato A, Tanifuji S (1989) Nucleotide sequences of the 5.8S rRNA gene and internal transcribed spacer regions in carrot and broad bean ribosomal DNA. J Mol Evol 29:294-301 